\title{
Bioedusiana
}

http://jurnal.unsil.ac.id/index.php/bioed

DOI: https://doi.org/10.37058/bioed.v6i1.2919

\section{Pengaruh Penggunaan Model Pembelajaran Synectics Untuk Meningkatkan Kemampuan Berpikir Kreatif Dan Hasil Belajar Siswa}

\author{
The Influence Of Using Synectics Learning Models To Improve Students' Creative Thinking Skills And \\ Learning Outcomes
}

\author{
Siti Rahmaniati ${ }^{1 *}$, Risa Umami ${ }^{2}$ \\ 1,2 Program S1 Pendidikan IPA Biologi Universitas Islam Negeri Mataram \\ J1. Gajah Mada Pagesangan 100, Jempong Baru, Kec. Sekarbela, Kota Mataram, NTB
}

\begin{abstract}
Abstrak
Kemampuan berpikir kreatif dan hasil belajar siswa pada dasarnya dapat ditingkatkan dengan berbagai macam cara salah satunya adalah dengan menggunakan model pembelajaran yang tepat pada saat proses pembelajaran yaitu menggunakan model pembelajaran Synectics. Penelitian ini bertujuan untuk mengetahui peningkatan kemampuan berpikir kreatif dan hasil belajar siswa dikelas VIII SMPN 3 Batukliang Utara pada materi sistem pencernaan manusia. Penelitian ini dilaksanakan pada bulan Agustus 2020. Metode penelitian yang digunakan adalah Quasi Eksperimental Design. Populasi dalam penelitian adalah seluruh kelas VIII sebanyak 2 kelas dengan jumlah total siswa sebanyak 50. Sampel yang digunakan sebanyak 2 kelas yaitu kelas VIII A sebagai kelas eksperimen dan VIII B sebagai kelas kontrol yang diambil secara sampling jenuh. Teknik pengumpulan data berupa tes kemampuan berpikir kreatif dan hasil belajar yang dilakukan sebelum dan sesudah dilakukan perlakuan. Instrumen yang digunakan adalah angket kemampuan berpikir kreatif dan hasil belajar berupa tes soal uraian pada materi sistem pencernaan manusia. Data hasil penelitian dianalisis menggunakan uji t independen dengan taraf signifikansi 5\%. Hasil penelitian menunjukkan bahwa ada pengaruh penggunaan model pembelajaran Synectics terhadap peningkatan kemampuan berpikir kreatif dan hasil belajar siswa yang diajar menggunakan model pembelajaran Synectics.
\end{abstract}

Kata kunci: Model Pembelajaran Synectics; Kemampuan Berpikir Kreatif; Hasil Belajar

\begin{abstract}
The ability to think creatively and student learning outcomes can basically be improved in various ways, one of which is by using the right learning model during the learning process, namely using the Synectic's learning model. This study aims to determine the increase in creative thinking skills and student learning outcomes in class VIII SMPN 3 Batukliang Utara on the human digestive system. This research was conducted in August 2020. The research method used was Quasi Experimental Design. The population in this study was all class VIII as many as 2 classes with a total number of students as many as 50. The samples used were 2 classes, namely class VIII $A$ as the experimental class and VIII B as the control class which were taken by saturated sampling. Data collection techniques in the form of tests of creative thinking skills and learning outcomes were carried out before and after treatment. The instrument used is a creative thinking ability questionnaire and learning outcomes in the form of a description test on the material of the human digestive system. The research data were analyzed using an independent $t$ test with a significance level of $5 \%$. The results showed that there was an effect of using the Synectic's learning model on increasing creative thinking skills and student learning outcomes who were taught using the Synectic's learning model.
\end{abstract}

Keywords: Synectic's Learning Models; Creative Thinking Skills; Learning Outcome.

Article History

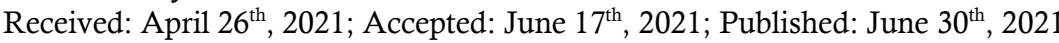

Corresponding Author*

Siti Rahmaniati, Program Studi IPA Biologi UIN Mataram, E-mail: niarahma100498@gmail.com

(C) 2021 Bioedusiana. This is an open access article under the CC BY-SA 4.0 license

(https://creativecommons.org/licenses/by-sa/4.0/) 


\section{PENDAHULUAN}

Pendidikan pada dasarnya adalah pengetahuan, keterampilan, dan kebiasaan sekelompok orang yang diturunkan dari satu generasi ke generasi berikutnya melalui pengajaran, pelatihan, atau penelitian. Secara detail, dalam undang-undang RI No 20 Tahun 2003 tentang Sistem Pendidikan Nasional Bab 1 pasal 1 (1) merupakan usaha sadar dan terencana untuk mewujudkan suasana belajar dan proses pembelajaran yang bertujuan agar siswa secara aktif mengembangkan potensi dirinya untuk memiliki kekuatan spiritual keagamaan, pengendalian diri, kepribadian diri, kecerdasan, akhlak mulia, serta keterampilan yang diperlukan bagi diri sendiri, masyarakat, bangsa dan negara (Sukardiman, 2010).

Menurut (Insyasiska et al., 2015) menyatakan bahwa tujuan dari pendidikan adalah untuk membangun intelegensi peserta didik agar mampu menghadapi permasalahan yang ada di sekitar. Sehingga, pendidikan diharapkan mampu mengembangkan potensi peserta didik agar menjadi manusia yang beriman dan bertakwa kepada Tuhan Yang Maha Esa, berakhlak mulia, sehat, berilmu, cakap, kreatif, mandiri, dan menjadi warga negara yang demokratis serta bertanggung jawab. Pencapaian tujuan pendidikan diperlukan perencanaan yang matang dalam bentuk kurikulum. Secara definisi, kurikulum adalah segala kegiatan dan pengalaman belajar yang dirancangkan, direncanakan, diprogramkan, dan diselenggarakan oleh lembaga bagi anak didiknya dengan maksud untuk mencapai tujuan pendidikan yang dapat mewujudkan visi, misi dan lembaganya (Setiana, 2020). Oleh karena itu untuk menunjang keberhasilan sebuah lembaga pendidikan harus ditunjang hal-hal sebagai berikut: adanya tenaga yang kompeten, adanya fasilitas yang memadai, adanya fasilitas bantu sebagai pendukung, adanya tenaga penunjang pendidikan seperti tenaga administrasi, pembimbing, pustakawan, laboratorium, adanya dana yang memadai, adanya manajemen yang baik dan terpeliharanya budaya menunjang seperti religius, moral, kebangsaan dan lain-lain.

Proses pembelajaran yang baik seperti yang sudah dinyatakan oleh (Sariningsih, 2020) apabila penyampaian materi dari seorang guru kepada siswanya tercapai. Sehingga, penggunaan model pembelajaran yang tepat dalam proses belajar mengajar sangat menentukan keberhasilan siswa. Keberhasilan tersebut dapat dilihat dari kemampuan siswa dalam memahami dan menguasai materi ajar yang disampaikan dan salah satu keberhasilan siswa dalam proses belajar yaitu dilihat dari hasil belajar peserta didik yang dicapai. Permasalahan yang sering terjadi pada dunia pendidikan yang hanya dominannya proses belajar mengajar masih dilakukan secara konvensional seperti uang sudah dijelaskan oleh (Rumbekwan et al., 2018) berdampak pada siswa yang tidak terbiasa belajar mandiri yang mengakibatkan siswa menjadi malas dan pasif selama proses pembelajaran. Rendahnya daya serap siswa dalam proses pembelajaran yang hanya berorientasi pada penguasaan sejumlah informasi atau konsep belaka yang menuntut siswa untuk menguasai materi pembelajaran. Materi yang terdapat pada mata pelajaran IPA 
sebagian besar bersifat abstrak sehingga membutuhkan media yang sesuai dalam penyampaiannya.

Penekanannya hanya lebih pada mencari suatu jawaban yang benar terhadap soal-soal yang diberikan. (Kristanto \& Susilo, 2015) mengatakan proses pemikiran tertinggi mulai dari penemuan masalah, analogi, sehingga pada tahap berpikir kreatif jarang digunakan. Kurangnya strategi pembelajaran berpikir di sekolah berdampak pada siswa yang kurang aktif. Padahal, kemajuan ilmu pengetahuan dan teknologi menuntut sumber daya manusia yang tidak hanya sekedar memiliki pengetahuan saja tetapi juga memiliki keterampilan dalam menciptakan sesuatu yang kreatif. Keterampilan berpikir kreatif adalah kemampuan menciptakan sesuatu yang bersifat baru dan yang belum pernah ada sebelumnya dan sangat dibutuhkan oleh peserta didik ketika hendak menyelesaikan masalah yang dijumpainya baik di sekolah maupun lingkungan. Dalam kehidupan sehari-hari keterampilan berpikir kreatif sangat penting. Menurut (Carin et al., 2013) kemampuan menciptakan sesuatu yang bersifat baru dan yang belum pernah ada sebelumnya. Kenyataan yang sering dijumpai di sekolah pembelajaran yang diterapkan belum menunjukkan metode yang dapat mengembangkan keterampilan kemampuan berpikir kreatif dan hasil belajar. Padahal keterampilan ini sangat penting dalam proses pembelajaran karena dengan cara berpikir dapat mempengaruhi kemampuan dan efektivitas pembelajaran (Widiawati et al., 2019).

Berdasarkan hasil wawancara di SMPN 3 Batukliang Utara Tahun Pelajaran 2020/2021, diperoleh informasi bahwa mata pelajaran IPA merupakan salah satu pembelajaran yang terbilang cukup sulit terutama pada materi sistem pencernaan manusia karena terdiri dari banyak pembahasan sehingga menyebabkan siswa merasa bosan pada saat proses pembelajaran berlangsung. Hal tersebut disebabkan karena guru belum bisa mencocokkan materi dengan model pembelajaran yang tepat. Untuk itu salah satu model pembelajaran yang tepat adalah model pembelajaran Synectics yang dapat membantu siswa dalam mengembangkan potensi yang dimilikinya sehingga siswa merasa termotivasi dalam belajar. Seperti yang diketahui sebelumnya nilai IPA dari kebanyakan siswa kelas A dan kelas B cenderung masih kurang. Pembelajaran kebanyakan diberi secara konseptual, hanya mengandalkan buku paket saja. Disamping itu juga, siswa kurang memiliki rasa ingin tahu, masih bergantung kepada siswa lain dan malu untuk bertanya Sehingga siswa menjadi pasif dan masih kesulitan untuk memahami materi secara keseluruhan. Konsep belajar juga lebih sering menggunakan metode ceramah. Hal ini menyebabkan siswa cepat merasa bosan dan kurang aktif selama proses pembelajaran sedang berlangsung. Sehingga terdampak pada hasil belajar IPA siswa di SMPN 3 Batukliang Utara rata-rata masih dibawah KKM yaitu kurang dari 75. Hal ini disebabkan oleh pemahaman siswa yang kurang terhadap materi pokok yang diajarkan (Asiathi, 2020) 
Berdasarkan permasalahan tersebut, penelitian yang dilakukan oleh tenaga pendidik perlu melakukan pembaruan dalam mengajar baik dari segi metode maupun model pembelajaran yang digunakan dalam proses belajar mengajar sehingga siswa lebih bersemangat lagi dalam menerima materi yang diajarkan (Triyanti \& Nulhakim, 2018).

Salah satu model pembelajaran yang memicu munculnya kreativitas adalah model pembelajaran Synectics. Model pembelajaran ini merangsang keterlibatan siswa dalam membuat berbagai bentuk aktivitas metafora dan analogi, dengan demikian siswa dapat menciptakan pengertian baru di dalam pikirannya mengenai objek maupun situasi yang sedang dihadapi. (Aztry, 2012) dan dapat meningkatkan intelegensi dan mengembangkan kemampuan yang dimiliki oleh siswa. Kreativitas sangat dibutuhkan bagi siswa karena banyaknya tugas yang diberikan terutama yang berkaitan dengan masalah dalam kehidupan sehari-hari yang menuntut siswa untuk mengaplikasikan kemampuan berpikir kreatifnya. Sehingga mampu untuk menghadapi masalah, menemukan solusi dan berani untuk berargumentasi (Firdaus et al., 2018).

Adapun hasil penelitian yang telah dilakukan oleh (Nurokhmah et al., 2016) menunjukkan penerapan model pembelajaran Synectics dalam mengembangkan kreatifitas siswa terbukti lebih efektif dibandingkan menggunakan model pembelajaran lain, baik dalam segi mengembangkan keterampilan berpikir maupun dalam meningkatkan prestasi belajar. Sehingga, model pembelajaran ini diharapkan dapat mengembangkan kerangka berpikir peserta didik pada mata pelajaran IPA materi sistem pencernaan untuk mencapai salah satu tahapan berpikir tinggi yaitu berpikir kreatif. Berdasarkan latar belakang tersebut, maka penulis berminat untuk melakukan penelitian yang berjudul Pengaruh Penggunaan Model Pembelajaran Synectics Terhadap Peningkatan Kemampuan Berpikir Kreatif Dan Hasil Belajar Siswa Pada Materi Sistem Pernafasan Manusia Kelas VIII SMPN 3 Batukliang Utara.

\section{METODE}

\section{Jenis dan Desain Penelitian}

Jenis penelitian yang digunakan dalam penelitian ini adalah Quasi eksperimental design. terdapat dua kelompok yaitu kelas eksperimen dan kelas kontrol. Masing-masing kelas diberikan angket dan soal yang sama sebagai tes awal. Kemudian masing-masing kelas diberikan perlakuan yang berbeda, kemudian setelah perlakuan selesai masing-masing kelas diberikan angket dan soal yang sama dan dibandingkan hasilnya.

Desain yang digunakan dalam penelitian ini adalah desain dengan bentuk Nonequivalent Control Group Design. pada kelas eksperimen diajarkan menggunakan model pembelajaran Synectics sedangkan pada kelas kontrol diajarkan menggunakan model pembelajaran biasa yang sering diterapkan di sekolah. 


\section{Populasi dan sampel}

Populasi dalam penelitian ini adalah seluruh siswa kelas VIII di SMPN 3 Batukliang Utara yang terdiri dari dua kelas yaitu kelas A dengan jumlah siswa 25 orang dan kelas B dengan jumlah siswa 25 orang. Masing-masing kelas memiliki sifat yang relatif sama. Sampel dalam penelitian ini adalah siswa kelas VIII A dan VIII B. Kelas VIII A dijadikan sebagai kelas eksperimen dan kelas VIII B dijadikan sebagai kelas kontrol. Adapun jenis sampel yang digunakan dalam penelitian ini adalah sampel jenuh karena seluruh anggota populasi dari kelas A dan kelas B dijadikan sampel.

\section{Prosedur Penelitian}

Penelitian ini dilakukan pada masa pandemi Covid-19 dengan cara mengikuti protokol kesehatan melalui 3 tahapan, yaitu sebelum penelitian, perencanaan, pelaksanaan penelitian.

1. Sebelum penelitian

a. Membuat surat ijin penelitian disekolah.

b. Melakukan observasi awal di sekolah lokasi penelitian.

c. Menentukan kelas yang akan dijadikan sebagai kelas eksperimen dan kelas kontrol.

2. Perencanaan

a. Membuat RPP untuk kelas eksperimen dan kelas kontrol sesuai dengan model pembelajaran yang digunakan.

b. Menyiapkan instrumen yang digunakan dalam penelitian berupa Buku Paket, LKS, angket serta soal uraian tentang sistem pencernaan manusia.

3. Pelaksanaan penelitian

a. Melakukan tes awal (pretest) pada masing-masing kelas setelah itu melakukan uji prasyarat berupa uji validitas dan uji reliabilitas terhadap masing-masing soal.

b. Melakukan penelitian pada masing-masing kelas menggunakan model pembelajaran yang telah ditentukan.

c. Melakukan tes akhir (posttest) pada masing-masing kelas menggunakan soal yang sama.

d. Mengumpulkan, mengelola dan menganalisis data hasil penelitian menggunakan bantuan aplikasi Excel dan SPSS 22.

e. Membuat data laporan hasil penelitian.

\section{Instrumen Penelitian}

Instrumen yang digunakan dalam penelitian ini berupa angket kemampuan berpikir kreatif dan soal uraian yang sudah diuji validitas dan reliabilitasnya. Angket ini terdiri dari 26 butir pernyataan yang terdari 13 indikator untuk mengetahui peningkatan kemampuan berpikir kreatif siswa setelah mengikuti pembelajaran menggunakan model pembelajaran Synectics. 
Sedangkan soal uraian terdiri dari 10 butir soal tentang sistem pencernaan manusia ini diberikan untuk mengukur peningkatan hasil belajar siswa. Sebagaimana yang ditampilkan pada Tabel 1 kisi-kisi instrumen angket kemampuan berpikir kreatif dan Tabel 2 kisi-kisi instrumen hasil belajar yang digunakan dalam penelitian ini.

Tabel 1. Kisi-Kisi Instrumen Angket Kemampuan Berpikir Kreatif Siswa

\begin{tabular}{|c|c|c|c|c|}
\hline \multirow[t]{2}{*}{ Aspek } & \multirow[t]{2}{*}{ Indikator } & \multicolumn{2}{|c|}{ No. Item } & \multirow[t]{2}{*}{ Jumlah } \\
\hline & & + & - & \\
\hline \multirow[t]{3}{*}{ Fleksibilitas } & $\begin{array}{l}\text { 1. Menghasilkan gagasan, jawaban atau } \\
\text { pertanyaan yang bervariasi }\end{array}$ & 2 & 1 & 2 \\
\hline & $\begin{array}{l}\text { 2. Dapat melihat suatu masalah dari sudut } \\
\text { pandang berbeda-beda }\end{array}$ & 3 & 4 & 2 \\
\hline & $\begin{array}{l}\text { 3. Mencari banyak alternatif atau arah yang } \\
\text { berbeda-beda }\end{array}$ & $6 ; 7$ & $5 ; 8$ & 4 \\
\hline \multirow[t]{3}{*}{ Orisinalitas } & $\begin{array}{l}\text { 4. Mampu melahirkan ungkapan yang baru } \\
\text { dan unik }\end{array}$ & 9 & & 1 \\
\hline & $\begin{array}{l}\text { 5. Memikirkan cara yang tidak lazim untuk } \\
\text { mengungkapkan diri }\end{array}$ & 10 & & 1 \\
\hline & $\begin{array}{l}\text { 6. Mempunyai kemauan keras untuk } \\
\text { menyelesaikan tugas }\end{array}$ & 11 & & 1 \\
\hline \multirow[t]{5}{*}{ elaborasi } & $\begin{array}{l}\text { 7. Menanggapi pertanyaan-pertanyaan } \\
\text { dengan penuh gairah, semangat dalam } \\
\text { menyelesaikan tugas-tugas }\end{array}$ & 13 & 12 & 2 \\
\hline & $\begin{array}{l}\text { 8. Berani menerima atau melaksanakan } \\
\text { tugas berat }\end{array}$ & $14 ; 15$ & 16 & 3 \\
\hline & $\begin{array}{l}\text { 9. Senang mencari cara atau metode yang } \\
\text { praktis dalam belajar }\end{array}$ & 17 & & 1 \\
\hline & 10. Kritis dalam memeriksa hasil pekerjaan & $18 ; 19$ & & 2 \\
\hline & 11. Agresif bertanya & $20 ; 21$ & & 2 \\
\hline \multirow[t]{2}{*}{ Fluency } & $\begin{array}{l}\text { 12. Mencetuskan banyak gagasan, jawaban, } \\
\text { penyelesaian masalah atau pertanyaan }\end{array}$ & $22 ; 23$ & $24 ; 25$ & 4 \\
\hline & $\begin{array}{l}\text { 13. Mandiri dalam belajar materi yang } \\
\text { disampaikan oleh guru }\end{array}$ & 26 & & 1 \\
\hline
\end{tabular}

Penskoran:

a. Untuk pernyataan yang negatif: Sangat Sering $(\mathrm{SS})=5$, Sering $(S)=4$, Kadang-Kadang $(\mathrm{KK})$ $=3$, Jarang $(\mathrm{J})=2$, Tidak Pernah $(\mathrm{TP})=1$

b. Untuk pernyataan yang negatif: Sangat Sering $(\mathrm{SS})=1$, Sering $(\mathrm{S})=2$, Kadang-Kadang (KK) $=3$, Jarang $(\mathrm{J})=4$, Tidak Pernah $(\mathrm{TP})=5$ 
Tabel 2. Kisi-Kisi Instrumen Hasil Belajar Siswa

\begin{tabular}{|c|c|c|c|c|c|c|c|}
\hline \multirow{2}{*}{ No } & \multirow{2}{*}{ Materi } & \multirow{2}{*}{$\mathbf{K}$} & \multicolumn{4}{|c|}{ Aspek Proses Kognitif yang Diukur } & \multirow{2}{*}{ Jumlah } \\
\hline & & & $\mathrm{C} 1$ & $\mathrm{C} 2$ & $\mathrm{C} 3$ & $\mathrm{C} 4$ & \\
\hline \multirow[t]{3}{*}{1} & Menjelaskan pengertian sistem & $\mathrm{K} 1$ & & & & & \\
\hline & pencernaan. & $\mathrm{K} 2$ & & & & & 1 \\
\hline & & K3 & & 1 & & & \\
\hline \multirow[t]{3}{*}{2} & Menyebutkan organ-organ yang & $\mathrm{K} 1$ & & & & & \\
\hline & terlibat dalam sistem pencernaan & $\mathrm{K} 2$ & & & & & 1 \\
\hline & manusia. & $\mathrm{K} 3$ & 2 & & & & \\
\hline \multirow[t]{3}{*}{3} & Menyebutkan keterkaitan struktur & $\mathrm{K} 1$ & & & & & \\
\hline & organ pencernaan dan fungsinya & $\mathrm{K} 2$ & & & & & 3 \\
\hline & & K3 & & & 4 & $3 ; 5$ & \\
\hline \multirow[t]{3}{*}{4} & Menjelaskan proses pencernaan & $\mathrm{K} 1$ & & & & & \\
\hline & dalam tubuh manusia. & $\mathrm{K} 2$ & 6 & & & & 1 \\
\hline & & K3 & & & & & \\
\hline \multirow[t]{3}{*}{5} & Menyelidiki terjadinya proses & $\mathrm{K} 1$ & & & & & \\
\hline & pencernaan mekanis dan kimiawi. & $\mathrm{K} 2$ & & 7 & & & 1 \\
\hline & & K3 & & & & & \\
\hline \multirow[t]{3}{*}{6} & Menjelaskan gangguan yang terjadi & $\mathrm{K} 1$ & & & & & \\
\hline & pada sistem pencernaan manusia. & $\mathrm{K} 2$ & & & & 8 & 3 \\
\hline & & K3 & $9 ; 10$ & & & & \\
\hline Total & & & 4 & 2 & 1 & 3 & 10 \\
\hline
\end{tabular}

\section{HASIL DAN PEMBAHASAN}

\section{Hasil}

Data yang diperoleh keseluruhan dari kelas eksperimen dan kelas kontrol disajikan pada

Tabel 3.

Tabel 3. Data Hasil Pretest-Posttest Angket Kemampuan Berpikir Kreatif (KBK) dan Hasil Belajar Kelas Eksperimen dan Kelas Kontrol

\begin{tabular}{lcccccccc}
\hline Statistik & \multicolumn{3}{c}{ Kelas Eksperimen } & \multicolumn{3}{c}{ Kelas Kontrol } \\
& KBK & \multicolumn{2}{c}{ Hasil Belajar } & \multicolumn{2}{c}{ KBK } & \multicolumn{2}{c}{ Hasil Belajar } \\
& Pretest & Posttest & Pretest & Posttest & Pretest & Posttest & Pretest & Posttest \\
\hline Maksimum & 73 & 97 & 70 & 100 & 67 & 83,1 & 68 & 98 \\
Minimum & 48 & 70 & 35 & 76 & 55 & 63,1 & 38 & 70 \\
Rentang & 25 & 27 & 35 & 24 & 12 & 20 & 30 & 28 \\
Rata-rata & 61 & 79 & 47,04 & 87,2 & 61 & 73 & 50,48 & 80 \\
Standar deviasi & 6,6 & 5,7 & 8,25 & 6,4 & 2,9 & 6,06 & 6,28 & 6,2 \\
\hline
\end{tabular}

Tabel 3 menunjukkan bahwa adanya peningkatan kemampuan berpikir kreatif dan hasil belajar siswa setelah diberikan perlakuan. Pada kelas eksperimen memiliki skor rata-rata 79 . Begitu dengan nilai rata-rata hasil belajar pada kelas eksperimen lebih besar dibandingkan kelas kontrol dengan selisih 7,2. 
Berdasarkan hasil uji prasyarat analisis telah dilakukan, seluruh data telah memenuhi kriteria normal dan homogen. Secara lengkap hasil uji prasyarat analisis ditampilkan pada Tabel 4 dan Tabel 5.

Tabel 4. Uji Normalitas Angket Kemampuan Berpikir Kreatif (Kbk) Dan Hasil Belajar Kelas Eksperimen Dan Kelas Kontrol.

\begin{tabular}{|c|c|c|c|c|c|c|c|c|c|}
\hline & \multirow[t]{2}{*}{ Kelas } & \multicolumn{3}{|c|}{ Shapiro-Wilk } & \multirow{2}{*}{\multicolumn{2}{|c|}{ Kelas }} & \multicolumn{3}{|c|}{ Shapiro-Wilk } \\
\hline & & Statistic & $\mathrm{df}$ & Sig. & & & Statistic & $\mathrm{df}$ & Sig. \\
\hline \multirow{4}{*}{$\begin{array}{l}\text { Hasil } \\
\text { angket } \\
\text { siswa }\end{array}$} & $\begin{array}{l}\text { Pretest } \\
\text { eksperimen }\end{array}$ & 975 & 25 & .773 & \multirow{4}{*}{$\begin{array}{l}\text { Hasil } \\
\text { belajar } \\
\text { siswa }\end{array}$} & $\begin{array}{l}\text { Pretest } \\
\text { eksperimen }\end{array}$ & 943 & 25 & .172 \\
\hline & $\begin{array}{l}\text { Posttest } \\
\text { eksperimen }\end{array}$ & 905 & 25 & .023 & & $\begin{array}{l}\text { Posttest } \\
\text { eksperimen }\end{array}$ & 945 & 25 & .194 \\
\hline & $\begin{array}{l}\text { Pretest } \\
\text { kontrol }\end{array}$ & 953 & 25 & .288 & & $\begin{array}{l}\text { Pretest } \\
\text { kontrol }\end{array}$ & 958 & 25 & .369 \\
\hline & $\begin{array}{l}\text { Posttest } \\
\text { kontrol }\end{array}$ & 901 & 25 & .020 & & $\begin{array}{l}\text { Posttest } \\
\text { kontrol }\end{array}$ & 942 & 25 & .168 \\
\hline
\end{tabular}

Tabel 5. Uji Homogenitas Angket Kemampuan Berpikir Kreatif (KBK) Dan Hasil Belajar Kelas Eksperimen Dan Kelas Kontrol

\begin{tabular}{|c|c|c|c|c|c|c|c|c|c|c|c|}
\hline & & $\begin{array}{l}\text { Levene } \\
\text { statistic }\end{array}$ & df1 & df2 & Sig. & & & $\begin{array}{l}\text { Levene } \\
\text { statistic }\end{array}$ & df1 & df2 & Sig. \\
\hline $\begin{array}{l}\text { Hasil } \\
\text { angket } \\
\text { siswa }\end{array}$ & $\begin{array}{l}\text { Based on } \\
\text { mean }\end{array}$ & .772 & 1 & 48 & .400 & $\begin{array}{l}\text { Hasil } \\
\text { belajar } \\
\text { siswa }\end{array}$ & $\begin{array}{l}\text { Based on } \\
\text { mean }\end{array}$ & .356 & 1 & 48 & .553 \\
\hline
\end{tabular}

Uji $t$ independen digunakan untuk menguji hipotesis yang diajukan dalam penelitian.

Uji hipotesis dilakukan karena data yang diperoleh telah memenuhi prasyarat analisis. Pada tabel 6 dan tabel 7. Disajikan data hasil uji hipotesis.

Tabel 6. Uji Hipotesis Angket Kemampuan Berpikir Kreatif Menggunakan Uji T Independen

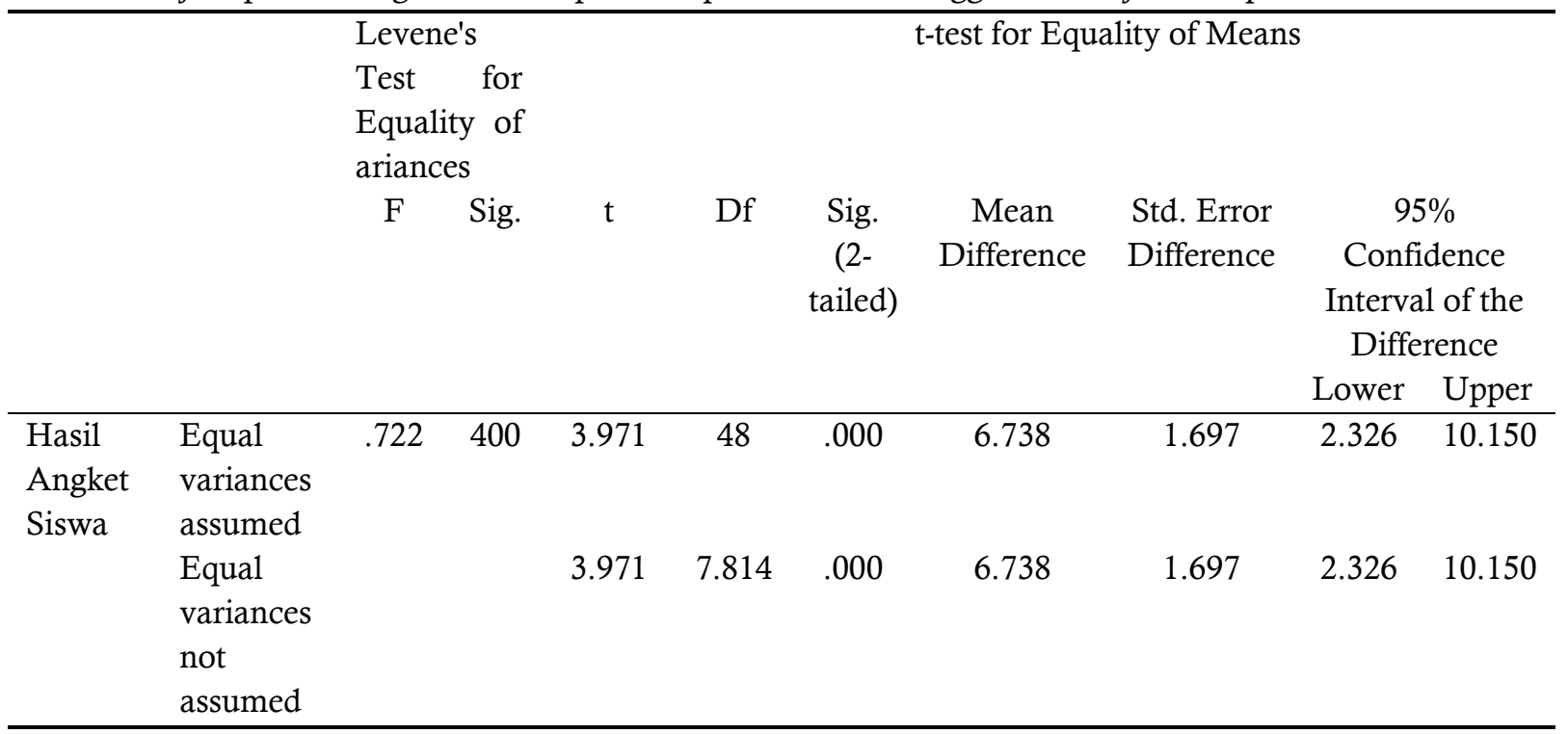


Tabel 7. Uji Hipotesis Hasil Belajar Menggunakan Uji T Independen

\begin{tabular}{|c|c|c|c|c|c|c|c|c|c|c|}
\hline & & \multicolumn{2}{|c|}{$\begin{array}{l}\text { Levene's Test } \\
\text { for Equality } \\
\text { of Variances }\end{array}$} & \multirow{3}{*}{$\mathrm{t}$} & \multirow{3}{*}{ Df } & \multicolumn{3}{|c|}{ t-test for Equality of Mean } & & \\
\hline & & $\mathrm{F}$ & Sig. & & & $\begin{array}{l}\text { Sig. } \\
(2- \\
\text { tailed })\end{array}$ & $\begin{array}{c}\text { Mean } \\
\text { Difference }\end{array}$ & $\begin{array}{l}\text { Std. Error } \\
\text { Difference }\end{array}$ & \multicolumn{2}{|c|}{$\begin{array}{l}95 \% \text { Confidence } \\
\text { Interval of the } \\
\text { Difference }\end{array}$} \\
\hline & & & & & & & & & Lower & Upper \\
\hline \multirow[t]{2}{*}{$\begin{array}{l}\text { Hasil } \\
\text { Belajar } \\
\text { siswa }\end{array}$} & $\begin{array}{l}\text { Equal } \\
\text { variances } \\
\text { assumed }\end{array}$ & .356 & .553 & 4.150 & 48 & .000 & 7.600 & 1.831 & 3.918 & 11.282 \\
\hline & $\begin{array}{l}\text { Equal } \\
\text { variances } \\
\text { not } \\
\text { assumed }\end{array}$ & & & 4.150 & 47.985 & .000 & 7.600 & 1.831 & 3.918 & 11.282 \\
\hline
\end{tabular}

Tabel 6 menunjukkan hasil uji hipotesis data angket kemampuan berpikir kreatif pada taraf signifikansi 5\%, didapatkan hasil nilai sig. 2 tailed sebesar 0,000 artinya nilai $\mathrm{t}_{\text {hitung }(.000)}<\mathrm{t}_{\text {tabel }}$ $(0,05)$, maka $\mathrm{H} 0$ ditolak dan Ha diterima yaitu terdapat pengaruh model pembelajaran Synectics terhadap peningkatan kemampuan berpikir kreatif siswa.

Tabel 7. Menunjukkan hasil uji hipotesis data hasil belajar pada taraf signifikansi $5 \%$,

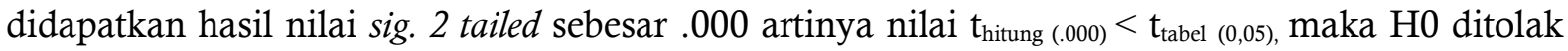
dan Ha diterima yaitu terdapat pengaruh model pembelajaran Synectics terhadap peningkatan hasil belajar siswa.

\section{Pembahasan}

Berdasarkan hasil penelitian yang telah dilakukan menggunakan uji hipotesis untuk mengetahui pengaruh penggunaan model pembelajaran Synectics terhadap peningkatan kemampuan berpikir kreatif dan hasil belajar siswa ini dapat disimpulkan terdapat pengaruh penggunaan model pembelajaran Synectics terhadap peningkatan kemampuan berpikir kreatif dan hasil belajar siswa pada materi sistem pencernaan manusia kelas VIII SMPN 3 Batukliang Utara. Adanya pengaruh ini disebabkan karena model pembelajaran Synectics menggunakan metode yang dapat memicu semangat dan minat belajar siswa sehingga siswa mampu mengasah kemampuan berpikir kreatif yang dimilikinya dan tidak menjadi pasif pada saat proses pembelajaran sedang berlangsung.

Penerapan model pembelajaran Synectics dapat membantu siswa untuk mengembangkan pengertian baru yang terdapat dalam diri peserta didik sehingga peserta didik sadar dalam menghadapi permasalahan serta mengembangkan pengertian yang dipahaminya tentang materi baru, dan dapat mengembangkan berpikir kreatif siswa serta membantu dalam menemukan cara berpikir baru untuk menyelesaikan masalah. Dari keunggulan tersebut model pembelajaran Synectics adalah siswa tidak terlalu menggantungkan diri pada guru, akan tetapi dapat menambah kepercayaan kemampuan berpikir sendiri. Sedangkan siswa dalam kelompok kontrol yang mendapatkan model pembelajaran biasa hanya diberikan metode konseptual dengan hanya mengandalkan buku paket saja disertai metode tanya jawab menjadikan siswa merasa bosan dan kurang aktif selama proses pembelajaran.

Berdasarkan kelebihan dari model pembelajaran ini, model pembelajaran ini sangat cocok untuk diterapkan dalam pembelajaran IPA. Karena guru dapat menerapkannya dalam membantu siswa mengembangkan kemampuan berpikir kreatif, baik dalam proses pembelajaran maupun dalam mengerjakan tugas. Dalam proses pembelajaran siswa diminta untuk berpikir eISSN: 2684-7604 / pISSN: 2477-5193 
secara kreatif dalam memecahkan masalah-masalah yang ada. Sehingga guru dapat membantu siswa dalam merangsang pemikiran kreatif sehingga tercipta kerjasama antara guru dengan siswa.

Pernyataan tersebut dapat didukung secara deskriptif berdasarkan hasil perolehan skor rata-rata posttest. Peserta didik yang diajarkan menggunakan model pembelajaran Synectics memperoleh nilai rata-rata kemampuan berpikir kreatif sebesar 79 dan hasil belajar sebesar 87,2. Sementara peserta didik pada kelas kontrol yang proses pembelajarannya menggunakan model pembelajaran biasa memperoleh nilai rata-rata kemampuan berpikir kreatif sebesar 73 dan hasil belajar sebesar 79,6. Berikut diagram skor rata-rata posttest angket kemampuan berpikir kreatif setiap indikator pada kelas eksperimen dan kelas kontrol.

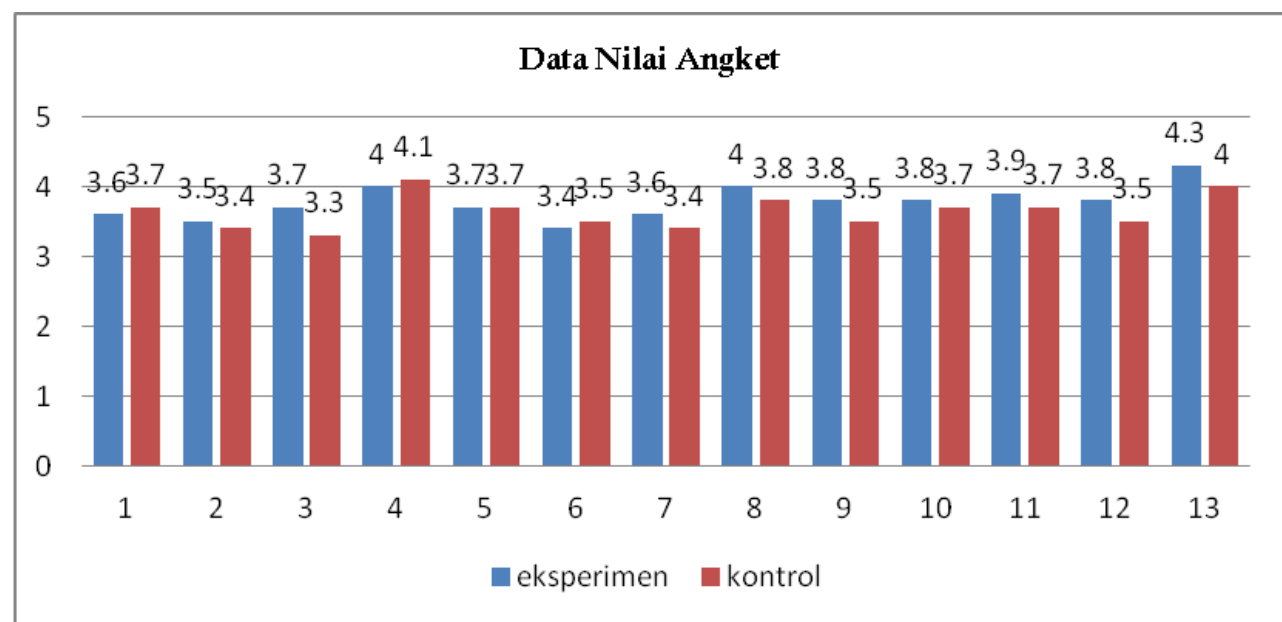

Gambar 1. Diagram Rata-Rata Skor Angket Kemampuan Berpikir Kreatif Setiap Indikator Kelas Eksperimen Dan Kelas Kontrol

Gambar 1 menunjukkan bahwa skor tertinggi angket kemampuan berpikir kreatif dicapai di kelas eksperimen pada indikator ke 13 yaitu mandiri dalam belajar materi yang disampaikan oleh guru dengan rata-rata skor 4,3. Hal ini dikarenakan siswa memiliki semangat dalam mempelajari materi yang telah disampaikan oleh gurunya. Sementara itu skor terendah angket kemampuan berpikir kreatif peserta didik terdapat pada indikator ke 6 yaitu mempunyai kemauan yang keras dalam menyelesaikan tugas dengan perolehan skor rata-rata sebesar 3,4. $\mathrm{Hal}$ ini dikarenakan peserta didik belum dapat menyelesaikan tugas dengan cepat. Disamping kedua indikator tersebut, ke sebelas indikator lainnya juga memiliki nilai yang cukup tinggi antara lain, menghasilkan gagasan, jawaban atau pertanyaan yang bervariasi sebesar 3,6, dapat melihat suatu masalah dari sudut pandang berbeda-beda sebesar 3,5, mencari banyak alternatif atau arah yang berbeda-beda sebesar 3,7, mampu melahirkan ungkapan yang baru dan unik sebesar 4, Memikirkan cara yang tidak lazim untuk mengungkapkan diri sebesar 3,7, menanggapi pertanyaan-pertanyaan dengan penuh gairah, semangat dalam menyelesaikan tugas-tugas sebesar 3,6, berani menerima atau melaksanakan tugas berat sebesar 4, senang mencari cara atau metode yang praktis dalam belajar sebesar 3,8, kritis dalam memeriksa hasil pekerjaan sebesar 3,8, agresif bertanya sebesar 3,9, dan mencetuskan banyak gagasan, jawaban, penyelesaian masalah atau pertanyaan sebesar 3,8. Hal ini menjelaskan bahwa adanya perubahan dalam model pembelajaran sangat berpengaruh pada minat belajar peserta didik. Sedangkan pada kelas kontrol nilai tertinggi angket kemampuan berpikir kreatif teradapat pada indikator ke 4 yaitu mampu melahirkan ungkapan yang baru dan unik sebesar 4,1 dan terendah pada indikator 3 yaitu mencari banyak alternatif atau arah yang berbeda-beda sebesar 3,3. Hal 
ini disebabkan karena pembelajaran berlangsung seperti biasanya tidak terdapat hal yang baru dalam mengembangkan potensi yang ada pada diri peserta didik.

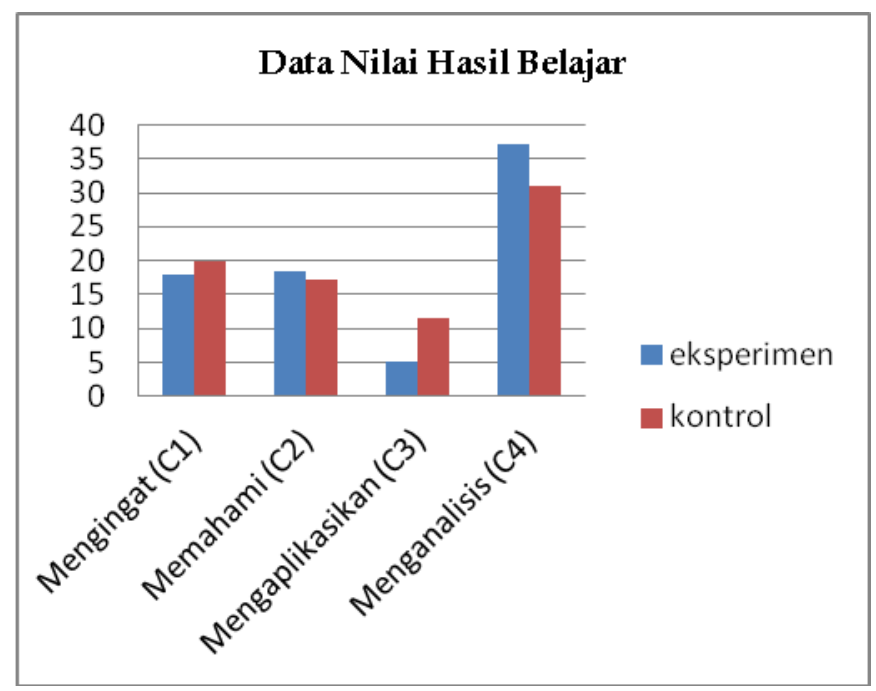

Gambar 2. Diagram Rata-Rata Skor Hasil Belajar Setiap Indikator Kelas Eksperimen Dan Kelas Kontrol

Gambar 2 menunjukkan ketercapaian tingkat kognitif peserta didik dapat dilihat dari hasil rata-rata perolehan skor. Skor tertinggi pada kelas eksperimen terdapat pada kategori menganalisis (C4) sebesar 37,1. Hal ini menunjukkan bahwa perubahan model pembelajaran dapat berpengaruh pada kemampuan berpikir tingkat tinggi siswa dalam menghubungkan materi dengan kehidupan nyata sehingga menjadi satu kesatuan. Sementara itu skor terendah terdapat pada tahap mengaplikasikan (C3) yaitu sebesar 5. Hal ini dikarenakan siswa belum dapat menerapkan materi yang telah diperoleh. Sama halnya dengan kelas eksperimen, perolehan skor tertinggi pada kelas kontrol terdapat pada kategori menganalisis (C4) sebesar 31 dan skor terendah terdapat pada kategori penerapan (C3) sebesar 11,4. Pada kelas kontrol yang menggunakan model pembelajaran biasa peserta didik cenderung kurang bersemangat pada saat proses pembelajaran sedang berlangsung. Hal ini berdampak pada nilai yang diperoleh peserta didik.

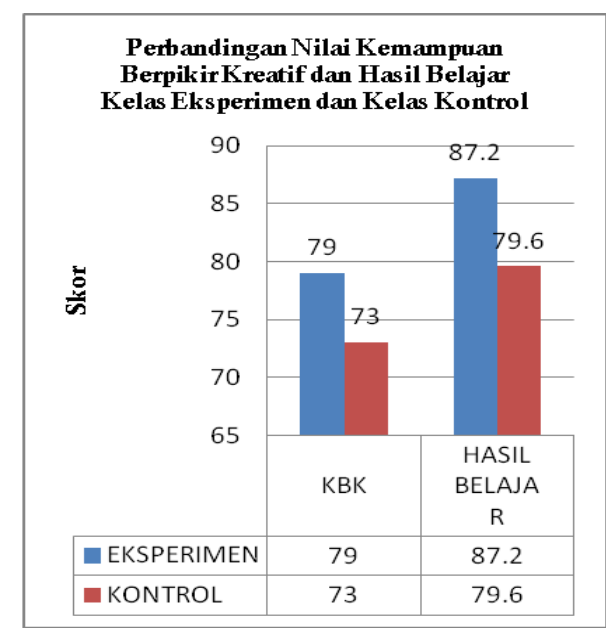

Gambar 3. Diagram Skor Rata-Rata Posttest Kemampuan Berpikir Kreatif Dan Hasil Belajar Kelas Eksperimen Dan Kelas Kontrol 
Uraian tersebut diperkuat dari hasil penelitian oleh (Agustina et al., 2016) dalam penelitiannya menyatakan bahwa model pembelajaran Synectics ini berpengaruh terhadap hasil belajar siswa karena dapat mendorong siswa lebih berpikir kritis serta tepat dalam mengidentifikasi, memahami, memecahkan masalah, mengaplikasikan materi pembelajaran sehingga siswa lebih mudah mengingat materi pembelajaran yang telah diberikan guru.

Munawaroh et al., (2017) dalam penelitiannya menyatakan bahwa model pembelajaran Synectics dapat meningkatkan kreativitas siswa pada kelas III SD dalam materi menggambar imajinatif. Hal tersebut disebabkan oleh pembelajaran menggunakan model pembelajaran Synectics dapat membuat siswa lebih bersemangat, pembelajarannya menjadi menyenangkan, menarik serta para siswa dapat menggambar sesuatu yang unik yang berbeda dari yang lain.

Penelitian oleh (Suhana, 2019) dalam penelitiannya menyatakan bahwa model pembelajaran Synectics dapat meningkatkan kemampuan berpikir kritis dan kreatif matematis siswa, siswa yang diajarkan menggunakan model pembelajaran Synectics lebih baik secara signifikan, dan siswa memiliki kebiasaan positif untuk mengembangkan kemampuan berpikir kritis dan kreatif.

Dari hasil penelitian ini dapat disimpulkan bahwa uji model pembelajaran menunjukkan hasil belajar siswa yang diajar menggunakan model pembelajaran Synectics lebih baik dibandingkan menggunakan model pembelajaran biasa.

\section{SIMPULAN}

Berdasarkan hasil penelitian yang telah dilakukan maka dapat disimpulkan bahwa terdapat pengaruh model pembelajaran Synectics terhadap peningkatan kemampuan berpikir kreatif dan hasil belajar siswa materi sistem pencernaan manusia kelas VIII SMPN 3 Batukliang Utara.

\section{REFERENSI}

Agustina, S., Pasaribu, M., \& Saehana, S. (2016). Pengaruh Model Pembelajaran Sinektik Terhadap Hasil Belajar Fisika Pada Siswa Kelas X SMA Negeri 4 Palu. JPFT (Jurnal $\begin{array}{lllll}\text { Pendidikan Fisika } & \text { Tadulako } & \text { Online), } & 4(2), & 42 .\end{array}$ https://doi.org/10.22487/j25805924.2016.v4.i2.6059

Aztry, A. (2012). Keefektifan Model Sinektik Dan Penemuan Konsep Pada Pembelajaran Menulis Puisi Berdasarkan Tingkat Kemandirian Siswa Kelas Vii Smp. Seloka - Jurnal Pendidikan Bahasa Dan Sastra Indonesia, 1(2).

Carin, A.A. \& Sund, R. ., \& Isti, S. N. D. (2013). Peningkatan Kemampuan Berpikir Kreatif Siswa Melalui Model Pembelajaran Inkuiri Pada Mata Pelajaran Ilmu Pengetahuan Alam. Jurnal PGSD, 1(2), 1-14.

Sukardi, D. K. (2016). Pengantar pelaksanaan program bimbingan dan konseling disekolah. Rineka Cipta.

Firdaus, H. M., Widodo, A., \& Rochintaniawati, D. (2018). Analisis Kemampuan Berpikir Kreatif dan Proses Pengembangan Kemampuan Berpikir Kreatif Siswa SMP pada Pembelajaran Biologi. Assimilation: Indonesian Journal of Biology Education, 1(1), 21. https://doi.org/10.17509/aijbe.v1i1.11452

Insyasiska, D., Zubaidah, S., \& Susilo, H. (2015). Pengaruh Project Based Learning Terhadap 
Motivasi Belajar, Kreativitas , Kemampuan Berpikir Kritis , Dan. Jurnal Pendidikan Biologi, $7(1), 9-21$.

Kristanto, Y., \& Susilo, H. (2015). Pengaruh Model Pembelajaran Inkuiri Terbimbing Terhadap Kemampuan Berpikir Kritis Dan Hasil Belajar IPA Siswa Kelas VII SMP. Jurnal Pendidikan Dan Pembelajaran Universitas Negeri Malang, 22(2), 197-208.

Munawaroh, A. N., Jayadinata, A. K., \& Aeni, A. N. (2017). Penerapan Model Learning Cycle Untuk Meningkatkan Hasil Belajar Siswa Pada Materi Sifat-Sifat Cahaya. Jurnal Pena Ilmiah, 2 (1), 2051 - 2060.

Nurokhmah, N., Nurlaelah, I., \& Setiawati, I. (2016). Penerapan Model Sinektik Untuk Meminimalisir Konsep Keterampilan Berpikir Kreatif Siswa Kelas Xi Ipa Di Sma. 8(2), 54-62.

Rumbekwan, Y. O., Yohanita, A. M., \& Damopolii, I. (2018). Pengaruh Model Pembelajaran Cooperative Script terhadap Hasil Belajar Biologi di Kelas VIII SMP 11 Manokwari. JIPVA (Jurnal Pendidikan IPA Veteran), 2(1), 25. https://doi.org/10.31331/jipva.v2i1.566

Sariningsih. (2020). pengaruh model pembelajaran Guided inquiri terhadap hasil belajar kognitif materi sistem saraf manusia. Jurnal p;Endidikan Biologi, 12(1), 22-29. http://jurnal.unimed.ac.id/2012/index.php/JPB

Setiana. (2020). Kajian Kurikulum Sekolah Dasar dan Menengah. Diakses pada tanggal 28 juni 2021 pukul 10.06 AM Http://Eprints.MercubuanaYogya.Ac.Id/8920/1/Modul\%20kajian\%20kurikulum\%20sekolah\%20dasar\%20dan\%20m enengah_Proses.Pdf

Suhana. (2019). Upaya Peningkatan Berpikir Kritis Dan Berpikir Kreatif Siswa Pada Materi Aritmetika Sosial Dengan Menggunakan Model Pembelajaran Sinektik. 4(1), 42-48.

Syamilah Meidiyanti1, St. Syamsudduha, Eka Damayanti, J. (2021). Pengaruh Kemampuan Berpikir Kreatif Peserta Didik Melalui Pembelajaran Model Learning Cycle Engagement Exploration Explanation Elaboration Dan Evaluation Disertai Mind Mapping. Jurnal Pendidikan Biologi, 12(1), 16-21.

Triyanti, M., \& Nulhakim, U. (2018). upaya peningkatan hasil belajar biologi siswa kelas $x$ menggunakan model pembelajaran student acilitator and explaining. 1(1), 43-51.

Widiawati, W., Syamsurizal, S., \& Ardi, A. (2019). The Analysis of Creative Thinking Ability of VII Class Student in Biology Learning at SMPN 25 (Junior High School 25) Padang. Atrium Pendidikan Biologi, 4(4), 75-84.

Zuhaida Asiathi, Wawancara, Setiling, Pukul 09.00, Kamis 13 Agustus 2020 